\title{
PNEUMOCYSTIS PNEUMONIA DURING MEDICAMENTOUS TREATMENT OF CUSHING'S SYNDROME - A DESCRIPTION OF TWO CASES
}

\author{
Filip Gabalec ${ }^{1}$, Alžběta Zavřelová' ${ }^{1}$ Eduard Havel ${ }^{2}$, Jaroslav Cerman, jr. ${ }^{2}$, \\ Jakub Radocha ${ }^{1}$, Ioannis Svilias ${ }^{1}$, Jan Č́áp ${ }^{1}$
}

Charles University in Prague, Faculty of Medicine and University Hospital Hradec Králové, Czech Republic: Second Department of Internal Medicine ${ }^{1}$ and Department of Surgery ${ }^{2}$

Summary: Only a few cases of pneumocystis pneumonia (PCP) in Cushing's syndrome have been published in the literature so far. In the majority of these patients, the pneumonia occurred after reduction of the hypercortisolism with medicamentous treatment. We report two cases of PCP during conservative treatment of hypercortisolism.

We describe clinical, imaging and laboratory findings in two patients and review published cases of pneumocystits pneumonia in Cushing's syndrome.

A 60-year-old woman and 20-year-old man with Cushing's syndrome due to ectopic ACTH syndrome were treated at our department. Both developed pneumocystis pneumonia early after treatment with ketoconazole and ethomidate bromide had been introduced and the levels of cortisol rapidly decreased.

PCP prophylaxis in patients with high cortisolemia should be started before treatment of hypercortisolism in current practice. Gradual lowering of plasma cortisol should also reduce the risk of infection by Pneumocystis jiroveci.

Key words: Cushing's Syndrome; Cushing's disease; Pneumocystis; Opportunistic infection; Glucocorticoids

\section{Introduction}

The immunosuppressive effect of corticosteroids is well known and thus they are widely implemented in therapy. Opportunistic infections have been reported to occur in endogenous hypercortisolism in Cushing's syndrome at a rate of incidence of $11-17 \%$, the occurrence of which correlated with the severity of hypercortisolism $(5,6)$. Several case reports have been published describing Pneumocystis pneumonia (PCP) in Cushing's syndrome. Patients with Cushing's syndrome are likely to have a subclinical Pneumocystis jiroveci infection that manifests upon restored immune response. The mechanism of Pneumocystis infection following cortisol-lowering therapy has been previously proposed $(5,6,8)$. We describe two cases of severe PCP in Cushing's syndrome and discuss the issue of primary antibiotic prophylaxis.

\section{Case 1: Description}

A 60-year-old woman was admitted to a district hospital for hyperglycemia $25 \mathrm{mmol} / 1$ (ref. range 3.3-5.6 mmol/l), polyuria with polydipsia and severe hypokalemia $2.1 \mathrm{mmol} / \mathrm{l}$ (ref. range 3.5-5.1 mmol/1). There was no significant pathology in her medical or family history, with the exception of smoking 10 cigarettes a day for 25 years and weight loss of $5 \mathrm{~kg}$ over the last month. She did not use any drug treatment. On physical examination, mild hypertension of $150 / 90 \mathrm{mmHg}$ and muscle weakness were noted. Laboratory investigations revealed severe hypokalemia with alkalosis $\left(\mathrm{HCO}_{3}{ }^{-} 38.1 \mathrm{mmol} / 1\right.$, Base excess $\left.13.9 \mathrm{mEq} / \mathrm{l}\right)$ (detailed results in Table 1). A chest radiograph, echocardiography and abdominal ultrasonography were performed and revealed no pathology. Following consultation with a neurologist, mild polyneuropathy was diagnosed. Although potassium was supplemented aggressively, the serum potassium level remained low. The plasma cortisol level was above the upper limit of normal during the diurnal profile. After two weeks of hospitalization, the patient was transferred to our Department of Endocrinology. The initial level of plasma cortisol was $3150 \mathrm{nmol} / 1$ (ref. range $<650 \mathrm{nmol} / \mathrm{l}$ ), adrenocorticotropin hormone (ACTH) $250 \mathrm{pg} / \mathrm{ml}$ (ref. range 20-60 pg/ml), and urinary free cortisol (UFC) $13.630 \mathrm{nmol} / 24 \mathrm{~h}$ (ref. range $<270 \mathrm{nmol} / 24 \mathrm{~h}$ ). Luteinizing hormone (LH) and folliclestimulating hormone (FSH) were low; thyrotropin (TSH), free thyroid hormones and prolactin were in the reference range. We started a two-day dexamethasone suppression test (DST) with $0.5 \mathrm{mg}$ of dexamethasone every 6 hours. An abdominal computerized tomography (CT) scan was performed simultaneously before the end of the DST. Bilateral adrenal hyperplasia was revealed, as was a surprisingly asymptomatic pneumoperitoneum. No other tumour was seen. An urgent laparatomy with colostomy was performed at the Department of Surgery due to perforated bowel. Unfortu- 
nately, the DST was not completed, but results after the first day showed that the cortisol level was not at all suppressed and remained above the detection limit. No pituitary mass was seen on magnetic resonance imaging (MRI) and a highresolution CT scan of the chest was negative. Continuous treatment with ketoconazole and etomidate bromide was started at the intensive care-unit, with a reduction of cortisolemia to $1222 \mathrm{nmol} / \mathrm{l}$. Four days later the patient developed respiratory failure with infiltrates seen on a chest radiograph. Analysis of samples taken during bronchoalveolar lavage (BAL) revealed massive infiltration with $P$. jiroveci. Treatment with trimethoprim-sulfamethoxazole $(5 \mathrm{mg} / \mathrm{kg}$ of trimethoprim and $100 \mathrm{mg} / \mathrm{kg}$ of sulfamethoxazol divided, four times a day for 3 weeks) was started with a good clinical response. Antiviral therapy was initiated due to strong positivity of cytomegalovirus PCR. A petrosal sinus sampling did not show an inferior petrosal sinus - peripheral (IPS-P) gradient and ectopic secretion was diagnosed. Unfortunate- ly, no ectopic lesion was found on an octreotide scan, nor on a positron emission tomography (PET) scan. Bilateral adrenalectomy was performed with respect to progression of hypercortisolism and worsening of the patient's status. After the operation she is doing well on substitution therapy.

\section{Case 2: Description}

A 20-year-old, previously healthy man was admitted to the intensive care unit for acute respiratory failure due to pneumonia and salmonella infection. One week before admission he suffered from a recent pathological fracture of the lumbar vertebrae prompting a diagnosis of severe osteoporosis. After recovery from the infection, he was transferred to our department for further evaluation. A CT scan showed decalcification of the vertebral column with compressive fractures. Hypercortisolism (>1380 nmol/l) was present in his laboratory results and other hormonal

Tab. 1: Selected laboratory data.

\begin{tabular}{|c|c|c|c|}
\hline Variable & Reference Range, Adults & Case 1 & Case 2 \\
\hline \multicolumn{4}{|l|}{ Biochemistry } \\
\hline Glucose & $3.3-5.6 \mathrm{mmol} / 1$ & $10 \mathrm{mmol} / \mathrm{l}$ & $7 \mathrm{mmol} / \mathrm{l}$ \\
\hline Sodium & $135-148 \mathrm{mmol} / 1$ & $143 \mathrm{mmol} / \mathrm{l}$ & $131 \mathrm{mmol} / \mathrm{l}$ \\
\hline Potassium (mmol/l) & $3.5-5.1 \mathrm{mmol} / 1$ & $2.5 \mathrm{mmol} / 1$ & $4.2 \mathrm{mmol} / \mathrm{l}$ \\
\hline Chloride (mmol/l) & $95-107 \mathrm{mmol} / 1$ & $95 \mathrm{mmol} / \mathrm{l}$ & $97 \mathrm{mmol} / \mathrm{l}$ \\
\hline Calcium (mmol/l) & $2.17-2.65 \mathrm{mmol} / 1$ & $1.93 \mathrm{mmol} / \mathrm{l}$ & $2 \mathrm{mmol} / 1$ \\
\hline Ionizated Calcium (mmol/l) & $0.9-1.3 \mathrm{mmol} / 1$ & $1.2 \mathrm{mmol} / \mathrm{l}$ & $1.25 \mathrm{mmol} / \mathrm{l}$ \\
\hline Magnesium (mmol/l) & $0.66-1.07 \mathrm{mmol} / 1$ & $0.87 \mathrm{mmol} / 1$ & $0.87 \mathrm{mmol} / 1$ \\
\hline Phosphate (mmol/l) & $0.7-1.5 \mathrm{mmol} / 1$ & $0.79 \mathrm{mmol} / \mathrm{l}$ & $1.03 \mathrm{mmol} / \mathrm{l}$ \\
\hline Urea $(\mathrm{mmol} / \mathrm{l})$ & $2.5-8.3 \mathrm{mmol} / \mathrm{l}$ & $5.5 \mathrm{mmol} / \mathrm{l}$ & $6.3 \mathrm{mmol} / \mathrm{l}$ \\
\hline Creatinine (umol/l) & $50-115 \mathrm{umol} / 1$ & $52 \mathrm{umol} / 1$ & $61 \mathrm{umol} / 1$ \\
\hline LDH (ukat/l) & $2,25-3.55$ ukat/l & 8.28 ukat/1 & 4.27 ukat/1 \\
\hline Total protein $\mathrm{g} / \mathrm{l}$ & $65-80 \mathrm{~g} / 1$ & $50.9 \mathrm{~g} / 1$ & $38.1 \mathrm{~g} / 1$ \\
\hline Albumin $\mathrm{g} / \mathrm{l}$ & $35-52 \mathrm{~g} / 1$ & $27.2 \mathrm{~g} / 1$ & $18.5 \mathrm{~g} / 1$ \\
\hline CRP (mg/l) & $<5 \mathrm{mg} / \mathrm{l}$ & $13 \mathrm{mg} / \mathrm{l}$ & $11.4 \mathrm{mg} / \mathrm{l}$ \\
\hline \multicolumn{4}{|l|}{ Hormones } \\
\hline Thyrotropin - TSH (mIU/l) & $0.15-5.0 \mathrm{mIU} / 1$ & $0.99 \mathrm{mIU} / \mathrm{l}$ & $0.99 \mathrm{mIU} / \mathrm{l}$ \\
\hline free Thyroxin $(\mathrm{pmol} / \mathrm{l})$ & $11-25 \mathrm{pmol} / 1$ & $12.4 \mathrm{pmol} / 1$ & $11.6 \mathrm{pmol} / 1$ \\
\hline free Trijodthyronin (pmol/l) & $2.5-5.8 \mathrm{pmol} / \mathrm{l}$ & ND & $2.95 \mathrm{pmol} / 1$ \\
\hline Parathormon $(\mathrm{pg} / \mathrm{ml})$ & $13-50 \mathrm{pg} / \mathrm{ml}$ & ND & $18.2 \mathrm{pg} / \mathrm{ml}$ \\
\hline Cortisol (nmol/l) & $250-650 \mathrm{nmol} / 1$ & $3150 \mathrm{nmol} / \mathrm{l}$ & $>1380 \mathrm{nmol} / 1$ \\
\hline Adrenocorticotropin $(\mathrm{pg} / \mathrm{ml})$ & $20-60 \mathrm{pg} / \mathrm{ml}$ & $250 \mathrm{pg} / \mathrm{ml}$ & $300 \mathrm{pg} / \mathrm{ml}$ \\
\hline Urinary free cortisol (nmol/24h) & $<270 \mathrm{nmol} / 24 \mathrm{~h}$ & $13630 \mathrm{nmol} / 24 \mathrm{~h}$ & $1188 \mathrm{nmol} / 24 \mathrm{~h}$ \\
\hline Aldosteron $(\mathrm{nmol} / \mathrm{l})$ & $0.02-0.45 \mathrm{nmol} / 1$ & $0.24 \mathrm{nmol} / 1$ & $0.14 \mathrm{nmol} / 1$ \\
\hline Active renin (ng/l) & $0.1-60 \mathrm{ng} / \mathrm{l}$ & ND & $1.69 \mathrm{ng} / 1$ \\
\hline Index aldosteron-renin & $0-20$ & ND & 29.9 \\
\hline Follicle-stimulating hormone (FSH) U/1 man & $1.1-9.4 \mathrm{U} / 1$ & $\mathrm{x}$ & $1.72 \mathrm{U} / 1$ \\
\hline Luteinizing hormone (LH) U/1 man & $0.7-7.8 \mathrm{U} / 1$ & $\mathrm{x}$ & $2.12 \mathrm{U} / 1$ \\
\hline Follicle-stimulating hormone (FSH) U/1 woman & $26.8-112.6 \mathrm{U} / 1$ & $1.13 \mathrm{U} / 1$ & $\mathrm{x}$ \\
\hline Luteinizing hormone (LH) U/1 woman & $15.9-54 \mathrm{U} / 1$ & $0.27 \mathrm{U} / 1$ & $\mathrm{x}$ \\
\hline Prolactin ug/l man & $0-13.1 \mathrm{ug} / 1$ & $14.87 \mathrm{ug} / \mathrm{l}$ & $17.41 \mathrm{ug} / \mathrm{l}$ \\
\hline SHBG & $20-70$ & ND & 10.2 \\
\hline
\end{tabular}


causes of osteoporosis were excluded - parathyroid hormone $18.2 \mathrm{pg} / \mathrm{ml}$ (ref.range 13-50 pg/ml), calcium $2 \mathrm{mmol} / \mathrm{l}$ (ref. range $2.17-2.65 \mathrm{mmol} / \mathrm{l}$ ), ionized calcium $1.25 \mathrm{mmol} / \mathrm{l}$ (ref. range $0.9-1.3 \mathrm{mmol} / \mathrm{l}$ ), free thyroxine $11.6 \mathrm{pmol} / \mathrm{l}$ (ref. range 11-25 pmol/1). There was no suppression of cortisol during a 2-day DST, UFC was $1188 \mathrm{nmol} / 24 \mathrm{~h}$, ACTH 300 pg/ml, central hypogonadism was present and MRI showed pituitary microadenoma (see Figure 1). Treatment was started with ketoconazole and ethomidate bromide, with good response in lowering hypercortisolism (from an immeasurable level over $1380 \mathrm{nmol} / 1$ to $425 \mathrm{nmol} / 1$ in four days). Unfortunately, a fever erupted. Elevated inflammatory markers were found and pneumonia was detected on a chest radiograph (Figure 2). Following our recent experience with the previous patient in Case Study 1, we immediately commenced treatment with trimethoprim-sulfamethoxazol (5 mg/kg and $100 \mathrm{mg} / \mathrm{kg}$ di-

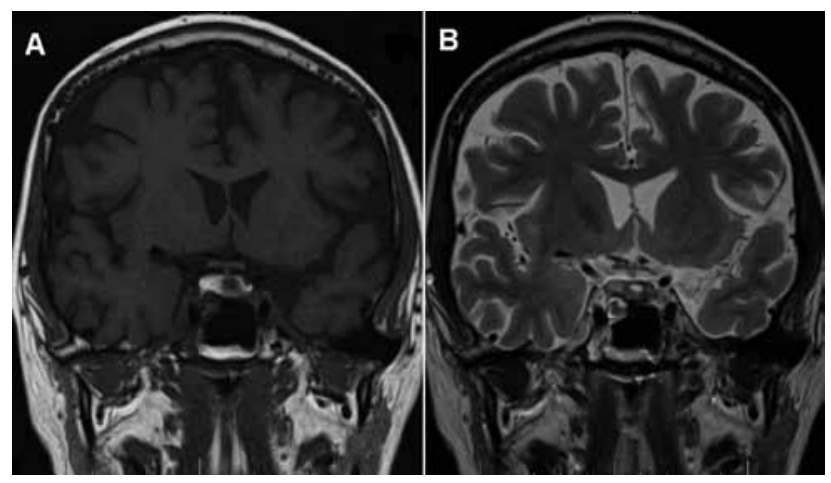

Fig. 1 (case 2): Magnetic resonance imagining of the head of the men patient before operation. A, T1 weighted image, showing and hypodense microadenoma $5 \times 6 \times 7 \mathrm{~mm}$. B, T2 weighted image with enhance signal of lesion.

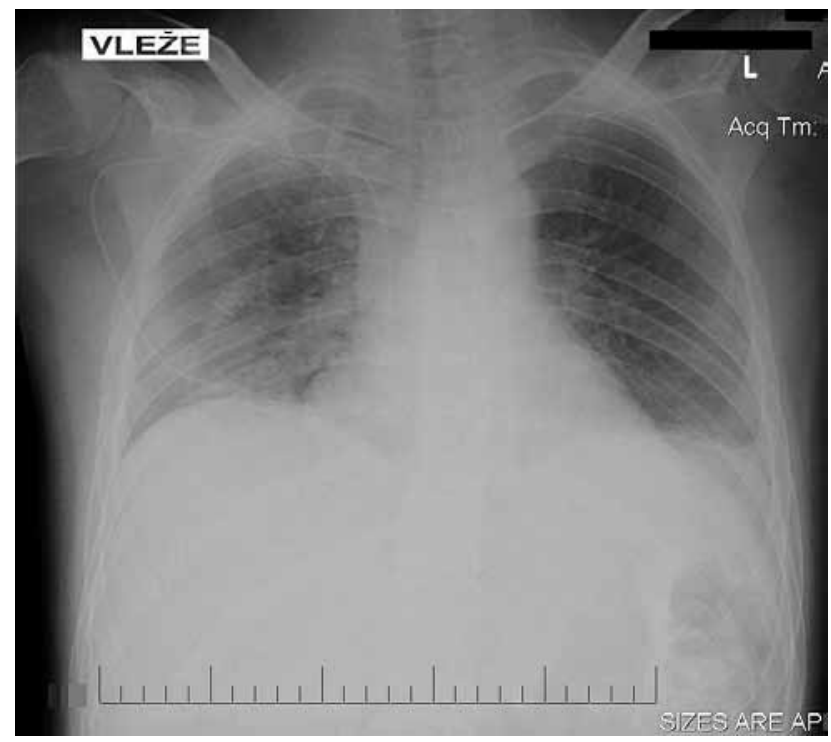

Fig. 2 (case 2): Chest radiograph (posterior-anterior) showing bilateral large infiltration. vided, four times a day) and broad-spectrum antimicrobial therapy. Pneumocystis pneumonia was confirmed by BAL but progression of respiratory failure demanded artificial ventilation. After recovery, the patient underwent radical pituitary adenomectomy. The hypercortisolism remained
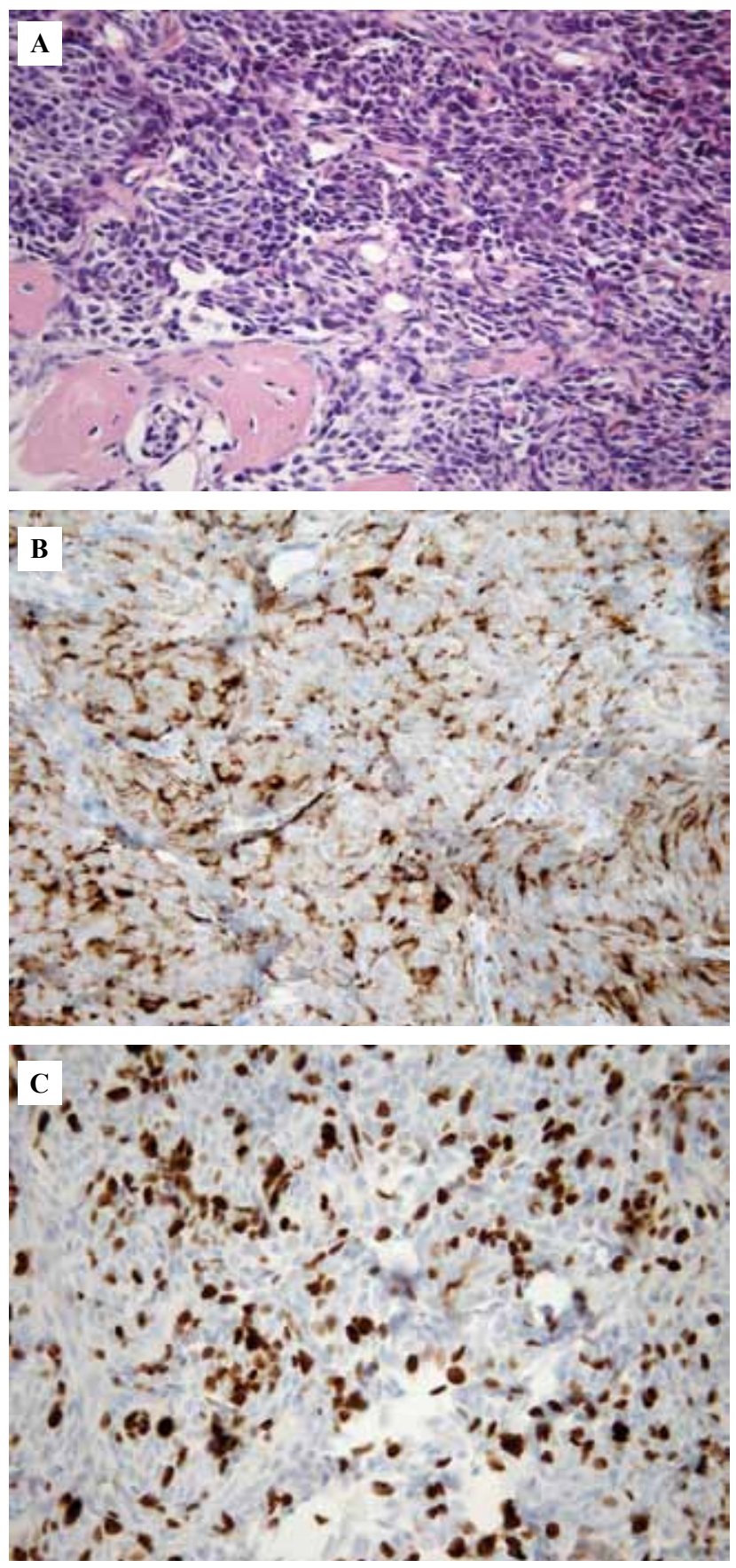

Fig. 3 (case 2): Histopathology images from a biopsy sample of the case patient's lumbar lesion in original magnification $\times 100$. A, Hematoxylin and eosin staining showing. B, Positive immunohistochemical staining for Ki-67. C, Positive immunohistochemical staining for ACTH. 
and both diabetes insipidus and panhypopituitarism developed. Further investigations should have been performed (high dose DST and inferior petrosal sinus sampling) and the pituitary surgery could have been avoided. The inferior petrosal sinus sampling was done only subsequently and did not show any gradient in ACTH secretion. The patient was indicated for bilateral laparoscopic epinephrectomy.

Positron emission tomography - computed tomography (PET-CT) revealed foci of high metabolism in mediastinal lymph nodes, retrosternally, and in the lumbar spine. The octreoscan was negative. Biopsy of the lumbar vertebra revealed a metastasis of high-grade endocrine carcinoma with Ki-67 index of 30\% and strong ACTH positivity (Figure 3 ). Chemotherapy has been started with tumour remission.

\section{Discussion}

Two cases of ectopic Cushing's syndrome (ECS) with manifestation of severe Pneumocystis pneumonia following cortisol-lowering therapy are described. $P$. jiroveci and a wide range of other opportunistic infections can occur in patients with hypercortisolism when the immune response is altered by the anti-inflammatory effect of glucocorticoids. It is supposed that alteration of immunity is glucocorticoids dose-dependent and the spectrum of opportunistic pathogens are the same in endogenous and exogenous hypercortisolism (4). In Sarlis's retrospective analysis of patients with ectopic Cushing's syndrome (not due to small-cell lung carcinoma to avoid confounding factors), serum cortisol, urinary free cortisol (UFC) and daily urine 17-hydroxysteroid were higher and correlated in patients with severe infectious complication (9). No correlation with temperature, white blood cell count, age, sex or localization of infection was observed. Higher levels of plasma cortisol in ECS are more common and the probability of infectious complications are more likely than in pituitary-dependent CS. An antibiotic prophylaxis has been suggested for $P$. jiroveci in patients with CS when plasma cortisol exceeds $2430 \mathrm{nmol} / \mathrm{L}$ (2). However, it seems difficult to determine any threshold. On the other hand, it seems that the fragile balance of the immune system is the cause of PCP manifestation after anti-inflammatory effects of steroids are attenuated. Asymptomatic carriage of pulmonary pneumocystis induced with cortisone acetate and development of pneumonia only after steroid withdrawal was demonstrated in rats (3). Thirty non-HIV cases of PCP after reversal of immunosuppression were described and reviewed previously, two of them with endogenous Cushing's syndrome (8). The first case of PCP after initiation of octreotide and ketoconazole treatment in ECS was described by Kim et al. (6). Later other cases were observed, with PCP after metyrapone in one patient (5), mifepristone in two ECS cases (10), after treatment with somatostatine analogue in ECS due to metastatic pancreatic islet cell carcinoma (7) and in other NETs (1). All authors suggest that prophylaxis should particularly be indicated in ECS. Generally, infection must be anticipated in patients with hypercortisolism and careful management with clinical monitoring is necessary. With respect to previous data and the fact that all clinical signs of infection can be attenuated in high cortisolemia, we conclude that PCP should be prevented in current practice. One possibility is commencing primary antibiotic prophylaxis in patients with high cortisolemia before medical treatment of hypercortisolism. Another prophylactic measure would be to screen patients for $P$. jiroveci by BAL or by induced sputum and only treat patients when $P$. jiroveci is detected.

Disclosure statement: F.G., A.Z., E.H., J.C., J.R., I.S. and J.Č. have nothing to declare.

\section{Acknowledgements}

This work was supported by the Internal Grant Agency of the Ministry of Health of the Czech Republic ( $\mathrm{N}^{\circ} 11344$ 4/2010)

\section{References}

1. Arlt A, Harbeck B, Anlauf M, Alkatout I, Kloppel G, Folsch UR, et al. Fatal pneumocystis jirovecii pneumonia in a case of ectopic Cushing's syndrome due to neuroendocrine carcinoma of the kidney. Exp Clin Endocrinol Diabetes. 2008 Oct; 116(9):515-9.

2. Bakker RC, Gallas PR, Romijn JA, Wiersinga WM. Cushing's syndrome complicated by multiple opportunistic infections. J Endocrinol Invest. 1998 May; 21(5):329-33.

3. Frenkel JK, Good JT, Shultz JA. Latent Pneumocystis infection of rats, relapse, and chemotherapy. Lab Invest. 1966 Oct; 15(10):1559-77.

4. Graham BS, Tucker WS, Jr. Opportunistic infections in endogenous Cushing's syndrome. Ann Intern Med. 1984 Sep; 101(3):334-8.

5. Keenan N, Dhillo WS, Williams GR, Todd JF. Unexpected shortness of breath in a patient with Cushing's syndrome. Lancet. 2006 Feb 4; 367(9508):446.

6. Kim DS, Park SK, Choi WH, Kim TW, Choi YY, Jeon SC, et al. Pneumocystis carinii pneumonia associated with a rapid reduction of cortisol level in a patient with ectopic ACTH syndrome treated by octreotide and ketoconazole. Exp Clin Endocrinol Diabetes. 2000; 108(2):146-50.

7. McQuillen DP, Schroy PC, Hesketh PJ, Sugar AM. Pneumocystis carinii pneumonia complicating somatostatin therapy of Cushing's syndrome in a patient with metastatic pancreatic islet cell carcinoma and Zollinger-Ellison syndrome. Am J Gastroenterol. 1991 Apr; 86(4):512-4.

8. Oosterhuis JK, van den Berg G, Monteban-Kooistra WE, Ligtenberg JJ, Tulleken $\mathrm{JE}$, Meertens JH, et al. Life-threatening Pneumocystis jiroveci pneumonia following treatment of severe Cushing's syndrome. Neth J Med. 2007 Jun; 65(6):215-7.

9. Sarlis NJ, Chanock SJ, Nieman LK. Cortisolemic indices predict severe infections in Cushing syndrome due to ectopic production of adrenocorticotropin. J Clin Endocrinol Metab. 2000 Jan; 85(1):42-7.

10. Wu AK, Cheng VC, Tang BS, Hung IF, Lee RA, Hui DS, et al. The unmasking of Pneumocystis jiroveci pneumonia during reversal of immunosuppression: case reports and literature review. BMC Infect Dis. 2004 Dec 9; 4(1):57.

Received: $18 / 12 / 2010$

Accepted in revised form: 30/06/2011

\section{Corresponding author:}

Filip Gabalec, MD, Second Department of Internal Medicine, Charles University Faculty of, Medicine and University Hospital in Hradec Králové,, Sokolská 581, 50005 Hradec Králové, Czech Republic; e-mail: gabalec@fnhk.cz 